Tanya Ball

\title{
The Power of Death: Hierarchy in the Representation of Death in Pre- and Post-Conquest Aztec Codices
}

\footnotetext{
7 hrough an examination of Aztec death iconography in preand post-Conquest codices of the central valley of Mexico (Borgia, Mendoza, Florentine, and Telleriano-Remensis),
} this paper will explore how attitudes towards the Aztec afterlife were linked to questions of hierarchical structure, ritual performance and the preservation of Aztec cosmovision. Particular attention will be paid to the representation of mummy bundles, sacrificial debtpayment and god-impersonator (ixiptla) sacrificial rituals. The scholarship of Alfredo López-Austin on Aztec world preservation through sacrifice will serve as a framework in this analysis of Aztec iconography on death. The transformation of pre-Hispanic traditions of representing death will be traced from these pre- to post-Conquest Mexican codices, in light of processes of guided syncretism as defined by Hugo G. Nutini and Diana Taylor's work on the performative role that codices play in re-activating the past. These practices will help to reflect on the creation of the modern-day Mexican holiday of Día de los Muertos.

\section{Introduction}

An exploration of the representation of death in Mexica (popularly known as Aztec) pre- and post-Conquest Central Mexican codices is fascinating because it may reveal to us the persistence and transformation of Aztec attitudes towards death and the after-life, which in some cases still persist today in the Mexican holiday Día de 
los Muertos, or Day of the Dead. This tradition, which hails back to pre-Columbian times, occurs every November 1st and 2nd to coincide with All Saints' Day and All Souls' day in the Christian calendar, and honours the spirits of the deceased.

Changes in the representation of Aztec death from pre- to postConquest times were in large part due to contact with European culture and Christianity through processes of guided syncretism. As noted by anthropologist Hugo G. Nutini, these processes of guided syncretism required functional or symbolic similarities between the two cultures (Aztec and European) and the political and economic domination of one tradition over the other. Important to the success of these cross-cultural negotiations was the willingness of those performing the conversion (Europeans) to be lenient towards the other culture (Aztecs) in order to maintain a rapid conversion rate (80-81).

In this context, Nutini's definition of guided syncretism will be helpful in this study on the representation of Aztec iconography on death in pre and post-Conquest codices because it will reveal that indigenous attitudes towards death persisted throughout the colonial period and do so even today. Through an examination of Aztec death iconography in pre- and post-Conquest codices of Central Mexico, this paper will explore how attitudes towards the Aztec afterlife were linked to questions of hierarchical structure and ritual performance (themes common both to Aztec and Christian traditions).

\section{Background and Literature:}

The concept of Aztec death and afterlife has certainly attracted the attention of many scholars. For example, Cecelia F. Klein has explored the Aztec obsession with death and sacrifice as based upon their conception of maintaining their cosmos (69). Louis M. Burkart has also explored the efforts of the Franciscan, Dominican, and 
Augustinian friars to convert the $16^{\text {th-century }}$ indigenous inhabitants of central Mexico. She has noted that the spiritual conquest of the Aztecs was successful in part due to the Friars adaptation of Christian rhetoric to Aztec language (Nahuatl) and worldview. For example, the Aztecs did not have an equivalent concept to Christian "sin", but given that the Aztecs did believe that human actions could disrupt the balance of their cosmos and destroy their world, the Franciscan friars decided to translate and associate the concept of "sin" and punishment with the end of days (79).

While the insights of scholars are crucial to an understanding of Aztec culture, it is prudent to consider a broader context concerning Aztec attitudes towards death. Aztec belief regarding death and the afterlife is a complicated matter as it is intricately intertwined with their cyclical calendar and their concept of the cosmos. Without death, the Aztecs believed that life would cease. Undoubtedly, then, elaborate rituals (some involving sacrifice) were employed throughout the Aztec calendar to ensure their continuation on earth.

The most documented aspect of Aztec practices related to the representation of death has been, for better or for worse, their participation in human sacrifice. The concept of sacrifice is of particular importance for this discussion on the representation of death because it reveals both their profound attitude towards the afterlife and offers insight into Aztec cosmovision.

Alfredo López Austin has provided a useful framework with which to analyze the different types of sacrifices that the Aztecs performed. López Austin has divided the Aztec concept of sacrifice into four categories, which will help in our understanding of the representation of death in the Aztec codices. He has labeled these four categories of sacrifice as the "images", the "beds", the "owners of skin", and the "payments" (376). 
López Austin notes how the category of sacrifice involving "images" was linked to the Aztec concept of ixiptla. As noted by Gruzinski, the ixiptla, did not exactly constitute an image, but referred to the various "manifestations of divinity" in the Aztec worldview (50). That is, an ixiptla could be an idol, a vision, or a representation of a god. More commonly, the term ixiptla signified a god impersonation, where a sacrificial victim was not only dressed to mimic a god's personal attributes, but the victim/participant actually became transformed into the god her/himself, here on earth through magical ritual time. Thus, by transforming the human sacrificial victim into a divinity, through the power of their sacred ritual calendar, " the power of a god was born, grew, decreased, and concluded, [which] made it necessary in a rite linking the time of man to mythical time that a god would die so his force might be reborn with new power" (López Austin 376). Therefore, according to Aztec cosmovision, if the gods were not sacrificed here on earth through human-god impersonators or ixiptla, their powers would diminish and ultimately the world would end.

The second category addressed by López Austin, "beds of the gods", refers to those who were killed in order to accompany the deceased. That is, the "images" or ixiptla gods on earth needed servants to serve as companions in the afterworld. In some cases, Aztec lords would have their bodies buried with a large group of servants so that they would provide domestic services in the afterlife (378).

The third category of sacrifice was the "owners of skin" that denoted the victims whose skins were removed and given to other men who would wear them during a type of ritual celebration and temporarily embody and be transformed into the god Xipe Totec ("Our Lord the Flayed One") (378). Besides providing transformative skins, this sacrifice also provided military trophies in the guise of 
body parts. The warrior who captured the sacrificial victim kept the femur of the captive, who then displayed it for all to see (378). This particular aspect of Aztec human sacrifice is important because it demonstrates a glorification of a militaristic discourse, which was rampant in the Aztec empire. This is evident in other practices as well beyond the male dominated military realm. For example, the Nahuatl word for a pregnant woman, conehua, meaning "my little captive", indicated that pregnant women were incorporated into militaristic discourse by viewing them as warriors who had little captives in their wombs.

Finally, the fourth category was the sacrificial debt- "payments". Here, "payments" refers to the fact that the gods were always hungry; they were starving and in need of a vital force. Man, dependent on the natural resources that were provided by the gods, was forced to replenish the gods through human sacrifice and blood. This concept of debt-payment through sacrifice is reinforced by the Aztec creation myth of Quetzalcoatl ("Feathered Serpent") and Tezcatlipoca ("Smoking Mirror") who transformed into serpents and tore apart their fellow female god, Tlateotl ("Earth or Filth Goddess"). This action of dismembering the Earth Goddess angered the other gods, so they attempted to make amends with Tlateotl by re-constructing the earth and all of human's necessities out of her dismembered body. What they didn't account for however, was Tlateotl's boundless hunger. When she wanted to eat, she refused to produce the amenities that humans needed to maintain their survival. To satisfy her hunger, the Aztecs needed to provide her with human sacrifices as food, otherwise the world would end (Michel Graulich, Myths of Ancient Mexico 50). Therefore, human sacrifice was seen as a type of nourishment or debt-payment to Mother Nature in order to ensure human existence. 
While this myth is crucial in conceptualizing "payments", it presents the relationship between humans and the gods as extremely one-sided. This was certainly not the case. According to Philip Arnold, "in a sacrificial context, the "debt" is the gift, or an understanding that human survival is dependent on an appropriate reciprocal relation with the deity" (81). This reciprocal relationship reveals a larger ecological network of recycling of gods and humans. Further, Arnold states that, "at some point, at some place, all life was food [...] having a place in the Aztec cosmos required that one participate in the constantly transforming quality of material life through the activity of eating" (163). In other words, all material life whether it be human, animal, plant, or divine were viewed as food. Therefore, death was not an end point, but a continuation of this ecological recycling system of vital and sacred fluids.

Representations of death in Pre-Conquest Mexico: "Debt-Payment" in the Codex Borgia

The representation of sacrifice through debt-payment can be seen in the pre-Colombian Codex Borgia. This particular codex holds great importance in the history of the Aztecs, as it is one of the few surviving pre-Conquest codices. An exact date and location as to where this codex was produced is largely debated, although it is generally believed that it was painted in the central highlands of Mexico (central or southern Puebla or the Tehuacan Valley) in the late fifteenth or early sixteenth century. It first came to the attention of scholarship in 1805 thanks to the Prussian scientific traveler Alexander Von Humboldt who encountered it in his travels through Rome. He noted that the codex belonged to Cardinal Stefano Borgia, who had received it from the Giustiniani family. Unfortunately, the Giustinani family entrusted the codex to his servants, who had given it to their children to use as a toy. Therefore, when it reached 
Humboldt, the manuscript had already been burnt and mistreated (Díaz and Rodgers xiv). Today, the Codex Borgia resides in the Apostolic Library of the Vatican in Rome, Italy and constitutes one of the few surviving pre-Colombian Aztec codices.

The manuscript itself comprises of 39 leaves. The leaves were made up of fourteen strips of animal skin, which were attached at each end (measuring up to $27 \mathrm{~cm}$ ) and folded into a screen fold book. The skin had a basecoat of white lime-plaster and it was painted with both mineral and vegetable pigments. The images painted within these leaves effectively present its religious content. It explores the ritual 260-day calendar, numerological prognostication, the cardinal directions of the world, and the characteristics of several gods. In this context, the codex presents us with an interesting outlook into the Aztec religion and cosmovision.

An image of particular interest to the representation of death can be found in the Codex Borgia. Figure 1 depicts two figures on either side pouring their own blood as a type of debt-payment intended towards, Tlateotl, the Earth Goddess. Here, the blood is seemingly transformed into two large heads of corn, the staple food of the Aztecs (Díaz, Rodgers, and Byland 25). Through an interpretation of this image in light of the creation myth of Quetzalcoatl and Tezcatlipoca, we can deduce that Tlateotl's hunger has been satisfied by the debt-payment of blood and, as a result, she is gifting the human race with bountiful produce. 


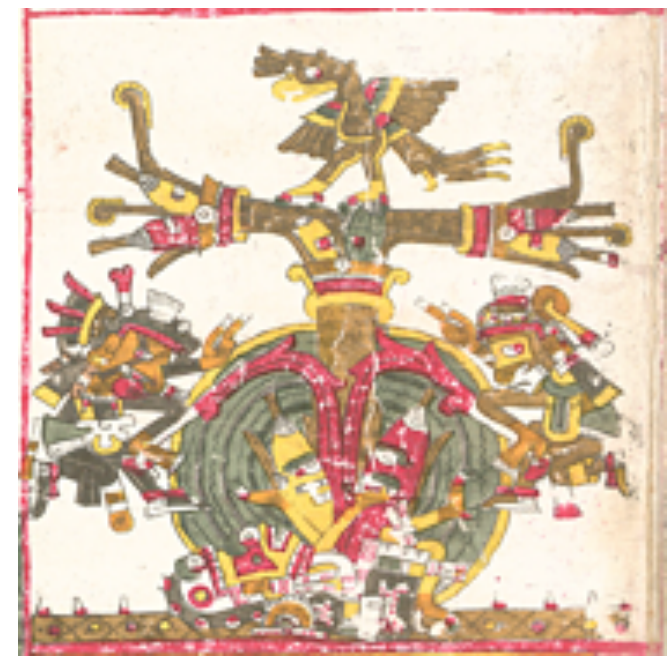

Figure 1. Aztec Self Sacrifice as "Debt-Payment" in the Codex Borgia accessed via the Foundation for the Advancement of Mesoamerican Studies, Inc. (FAMSI) on October 2, 2013. http://www.famsi.org/research/loubat/Borgia/page_53.jpg

While Figure 1 is a prime example of Aztec debt-payment through sacrifice, it only displays self-sacrifice. While the Aztecs also practiced self-sacrifice the amount of blood given depended on one's status in society. Thus noble women, lords, and priests were required to perform the most elaborate blood debt-payment, befitting to their rank.

Another example of debt-payment through sacrifice can be found in Figure 2 in the same Codex Borgia. This image offers a different aspect of the concept of debt-payment. Here, the image depicts several god-like figures sacrificing humans. Sprouting out from the victim's body are corn and other types of plants, further demonstrating that with sacrifice the Aztecs were provided with the necessities of life. 


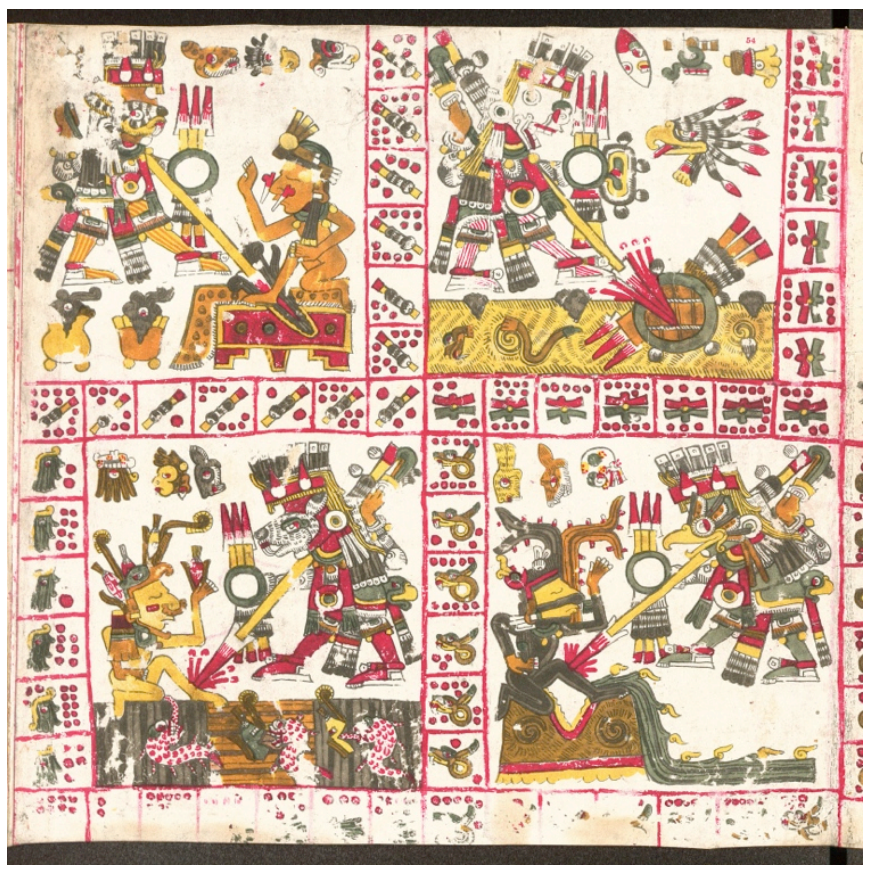

Figure 2. Human sacrifice in the Aztec 'Recycling' System from the Codex Borgia accessed via the Foundation for the Advancement of Mesoamerican Studies, Inc. (FAMSI) on October 2, 2013. http://www.famsi.org/research/loubat/Borgia/page_54.jpg

Because sacrifice perpetuated human existence, the representation of death is a principal subject in the Codex Borgia. For instance, in Figure 3-A the god of Death and the Underworld occupies a central place. At the center of the plate we have the appearance of Mictlantecuhtli ("Lord of Mictlan/The Place of Death"). Mictlantecuhtli's central position demonstrates his importance in the Aztec pantheon because the reader's eyes are directed towards him (see Figure 3-B). 


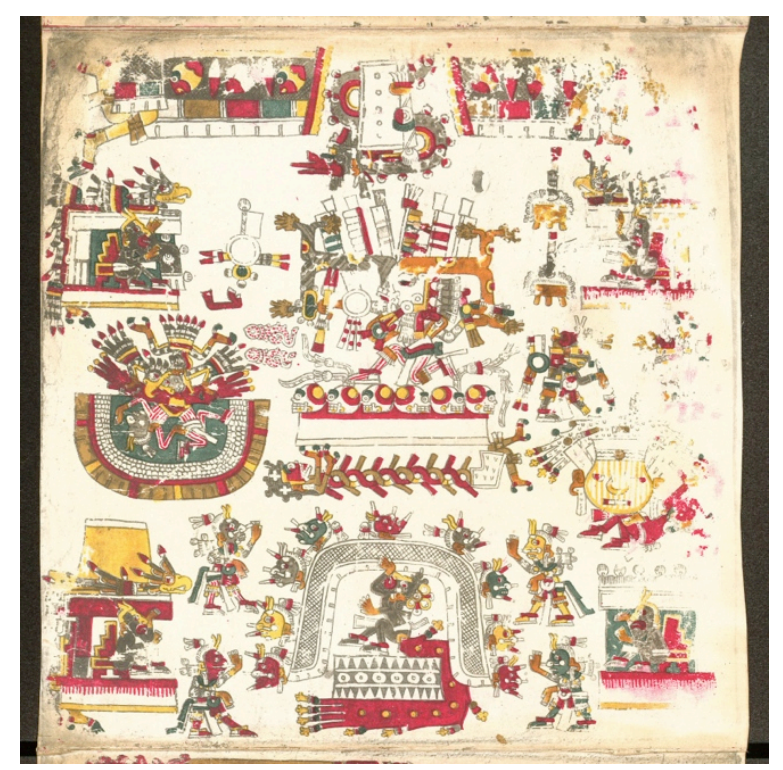

Figure 3-A. Aztec Death and the God Mictlantecuhtli from the Codex Borgia accessed via the Foundation for the Advancement of Mesoamerican Studies, Inc. (FAMSI) on October 2013. http://www.famsi.org/research/loubat/Borgia/page_45.jpg

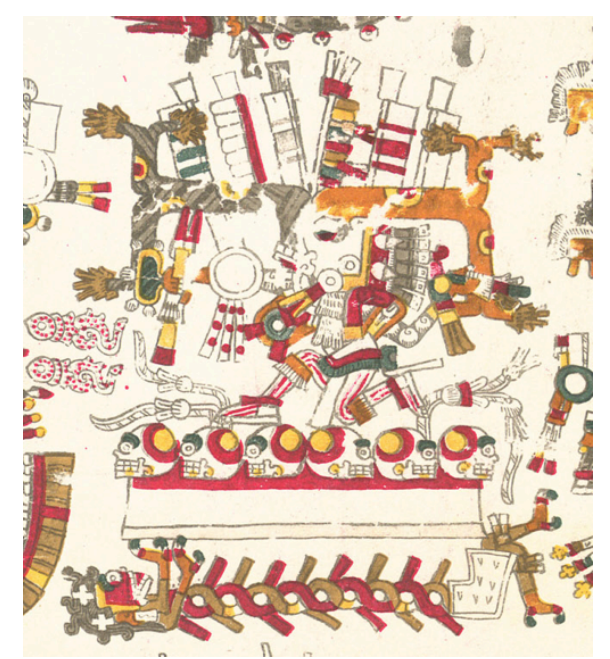

Figure 3-B. Close up of Mictlantecuhtli from Codex Borgia accessed via the Foundation for the Advancement of Mesoamerican Studies, Inc. $\begin{array}{llll}\text { (FAMSI) On } & \text { October } & 2013 .\end{array}$ http://www.famsi.org/research/loubat/Borgia/page_45.jpg

One of the most popular representations of death in the Codex Borgia is in the form of mummy bundles, which were used to represent deceased gods. This is evident in Figure 4-A, which depicts four deceased gods in the cardinal directions that are separated by 
four naked human figures in the four corners. Apart from their mummy bundle, each figure is perched upon a reed-like throne and is adorned with funerary attire and a set of elaborate paper flags, or funeral banners (see Figure 4-B for a close up of a mummy bundle).

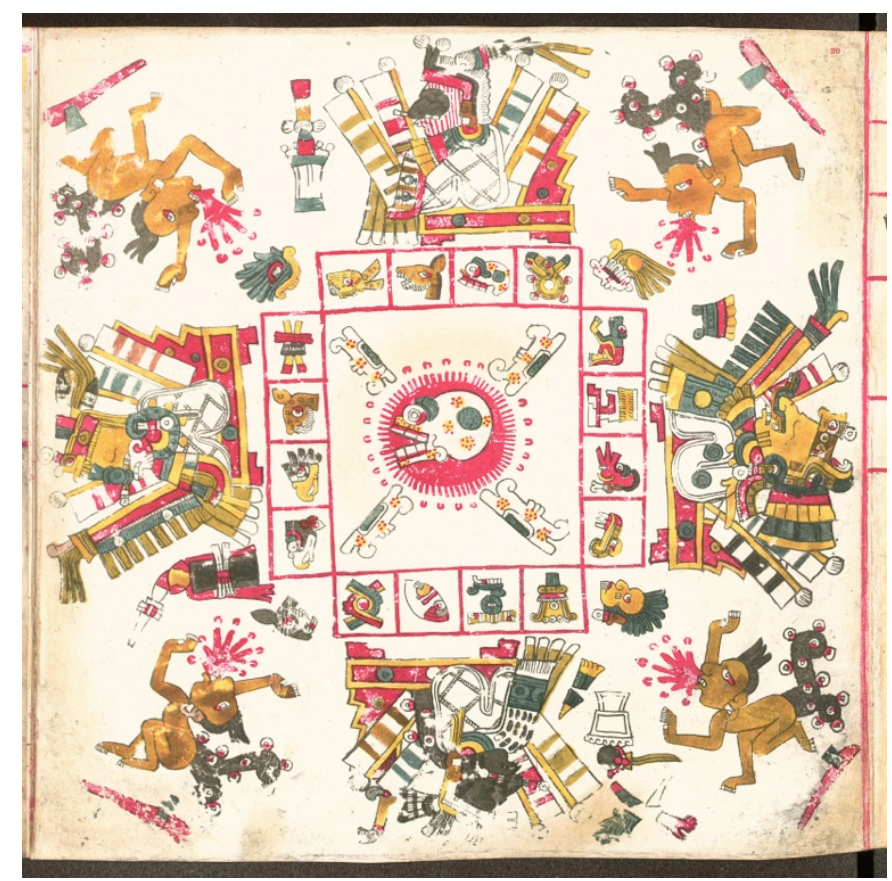

Figure 4-A. Deceased Gods Represented in Funerary Attire from the Codex Borgia accessed via the Foundation for the Advancement of Mesoamerican Studies, Inc. (FAMSI) on October 2, 2013. http://www.famsi.org/research/loubat/Borgia/page_26.jpg

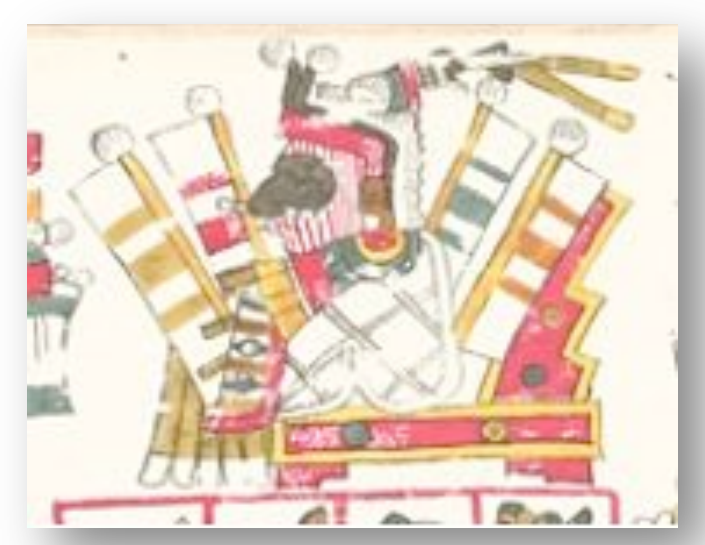

Figure 4-B. Close Up of a Deceased God in Funerary Attire from the Codex Borgia accessed via the Foundation for the Advancement of 
Mesoamerican Studies, Inc. (FAMSI) on October 2, 2013. http://www.famsi.org/research/loubat/Borgia/page_26.jpg

Bearing in mind the other figures in the image, the gods are clearly the more superior of the two. The human figures that are placed in between each god are represented in awkward, unflattering positions. In addition, they are depicted in the nude while the gods are in full garb. The elaborate clothing and mummy bundle that the gods possessed in death represents how Aztec society had a strict hierarchy of death. Furthermore the rich symbolic costumes of the gods indicate the importance of looking into the performance of funerary rites as represented in this and other codices.

Taking into account the representation of death in pre and postConquest codices, it is crucial to discuss the role of performance in Aztec ritual. In this regard, the work of Diana Taylor is insightful. In "Performance and/as History", Taylor challenges our concept of reconstructing the past which relies heavily upon archival study. She explains that the study of performance is crucial because it brings history into the present by reenacting scenarios from the past (68). With this in mind, one could consider the performative role of the codices as they served as a device for the Aztec priests to reactivate past events into a present ritual time (performance). Therefore, we can think of codices like scripts or plays that were to be performed (Monaghan 134). This concept bears particular importance when considering the previous image (Figure 4). If we view this image as a script of a play, then the priests took history that was represented in the codices and brought it into the present. In this particular instance, the priest would give life to the gods by reenacting their history through choreographed and musically accompanied public performance and thus, would blur the lines between the history of the living and the dead, the human and the divine worlds. 
If Aztec codices acted as scripts, then, one might ask who is the intended audience? Perhaps the answer to this question lies in the image itself or in the ritual that the image is representing. In the case of Figure 4, the initial reader/interpreter of the codex would be the priest who would use it as a script to direct a choreographed performance. Ultimately the final target audience of the codices' message would be the Aztec people because ritualized death and sacrifice aimed to represent, replicate, and preserve the hierarchal structure of the Aztec elite. That is, gods and lords were at the top of the hierarchy and commoner humans underneath them. This is emphasized in Figure 4 through the awkward representation of humans and the dignified representation of the divine.

We must remember of course that the target audience of the codices' message would also broaden to include the leaders and people of surrounding and subjugated tribes. For example, in the ritual month of Tlacaxipeualiztli, "Feast of the Flaying of Men", the Aztecs celebrated in honour of Xipe Totec, "Our Lord the Flayed One". Here, captive warriors from surrounding tribes or slaves were dressed as teotl ixiptla, the living image of Xipe Totec. As previously mentioned, in the context of ixiptla, the captives then transformed into the god were led through a series of rituals that they had to perform as Xipe Totec. Afterwards, the ixiptla were sacrificed and their body parts were dispersed accordingly. The entire city was present to witness the spectacle as well as strangers to the city. These strangers were generally rulers or nobles of the tribes that the Aztecs were at war with at the time (Carrasco 143-44). In this context, then, the audience was both the Aztec society and the foreign rulers of the surrounding tribes. By considering this example, we are able to assess the political landscape of Tenochtitlan, the Aztec capital. We can see that there was a hierarchy of death within 
Aztec society that also incorporated other tribes, where the Aztecs were portrayed as superior.

Representations of Death in various Post-Conquest Central Mexican Codices: Florentine, Mendoza, and Telleriano-Remensis

The arrival of the Spanish brought about a transitional period in Aztec society. This transition was mainly at the hands of the Christian missionaries, whose goal it was to create Christian communities in the New World. To succeed in such a mission, these missionaries (from the Franciscan, Dominican, the Augustinian orders) believed that they needed to enter in a dialogue with the indigenous people so that they could transform the Indians into model Christian citizens (Burkhart 5). This dialogue also entailed the beginnings of what we could call a type of guided syncretism. As previously noted, guided syncretism is based on the notion of different cultural practices coming together. However, guided syncretism relies upon the dominance of one tradition over the other and the willingness of those performing the conversion to be lenient towards the other culture (Nutini 80-81). This last requirement was of the upmost importance as many natives found themselves unable to relate to many of the foreign concepts of European religions. Therefore, many missionaries found themselves in a role reversal. That is, they took on the role of the students while the natives became the teachers. In doing this, the missionaries hoped to learn more about their culture so that they could better convert them into Christianity.

The transformation and persistence of Aztec views on death through guided syncretism is especially visible in post-Conquest codices. The most famous, and perhaps most renowned of these manuscripts, is that of the Spanish Franciscan Friar Bernardino de Sahagún who edited the sixteenth-century Historia general de la 
Nueva España, or what is today known as the Florentine Codex. The compilation and preparation for the manuscript began after Sahagún's arrival to New Spain in 1529. In his first years in New Spain, he actively sought and trained the male children of the surviving Aztec elite to collaborate with him on this project. It was in the Colegio de Tlatelolco in Mexico that he, along with hundreds of native students and elder informants, compiled the 12 -volume codex. The original intent behind the project was to learn more about the native population, so that the Franciscan friars could convert them into Christianity. Thus, each volume of the codex provides further insights into Aztec culture, ranging from their gods to their thoughts on the Conquest.

Among these insights, the codex examined many different aspects of death within Aztec society, which typically included the description of several rituals. One of which was a celebration named Toxcatl, the great feast dedicated to the important Aztec god Tezcatlipoca, "Smoking Mirror". This particular festival is worth noting because it recalls the political landscape that was presented previously in the earlier pre-Colombian Codex Borgia. Before divulging further into this topic, however, it is crucial to note the stylistic differences between the two codices discussed thus far. By doing this, one can further appreciate the changes in the representation of death before and after the conquest of Mexico, but, more importantly, this will help to showcase the challenge to and continuity of indigenous agency within this time frame.

With respect to the differences between European and Aztec forms of iconography, it is beneficial to consider the work of Ellen T. Baird. She describes the style of pre-Conquest codices as 'conceptual' (37). Images from this era were two-dimensional and all architectural and geographical entities were represented with signs. Human figures were generally posed unnaturally and separated into different units. 
These characteristics are evident when analyzing Figure 4. Regarding their overall shape, pre-Columbian manuscripts were folded in a way that mimicked an accordion. With this in mind, they could be folded and unfolded to expose the entire manuscript at one time.

In contrast, Baird explains that the sixteenth-century, European style of the post-Conquest codices was 'perceptual' and influenced by Renaissance three-dimensional representation. The European style showcased human figures, architectural, and geographic forms in a more naturalistic manner. Stylistically, artists employed techniques such as hatching, modeling, and contour lines (37). Moreover, the shape of the post-Conquest codices was arranged to look more like a European book, making it impossible to view the entire codex at once. The most obvious difference, however, was the presence of roman alphabetic text, which was a foreign concept to the Aztec people as they communicated mainly through imagery and the materiality of culture. These differences are clear when viewing Figures 5-A and B representing the Toxcatl ritual. 


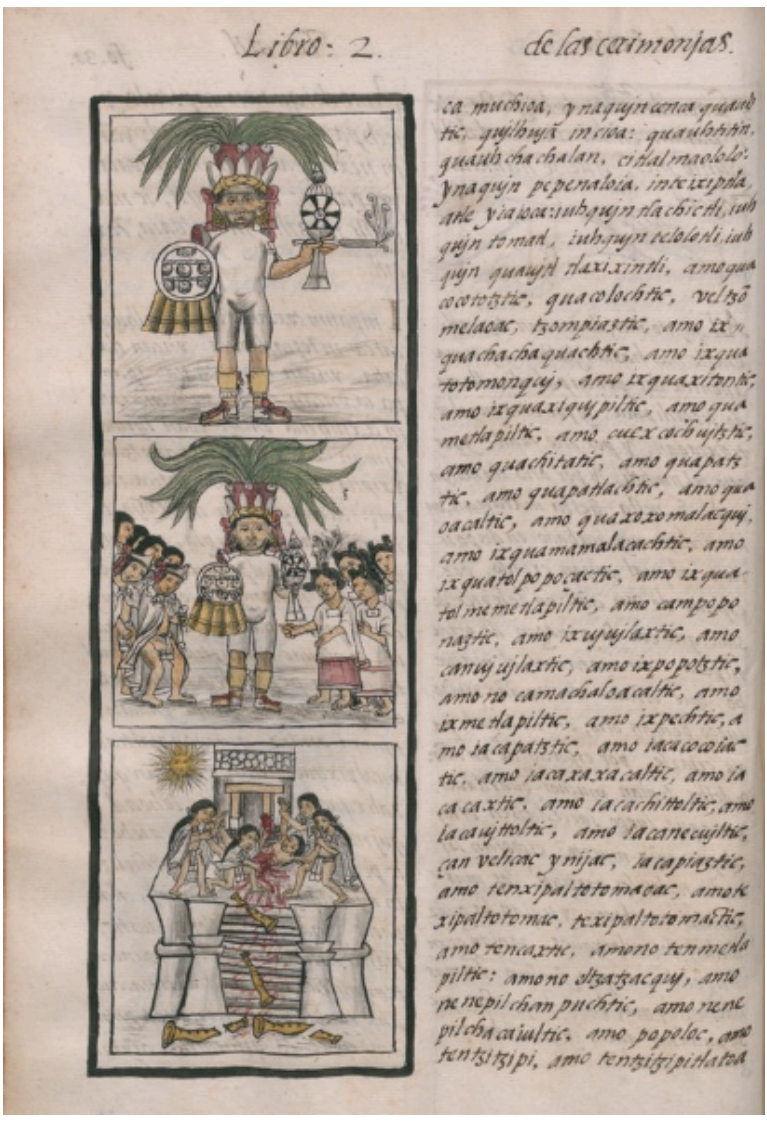

Figure 5-A. Toxcatl, The Great Feast of Tezcatlipoca from the Florentine Codex accessed via World Digital Library (WDL) on October 2, 2013. http://www.wdl.org/en/item/10613/view/1/37/

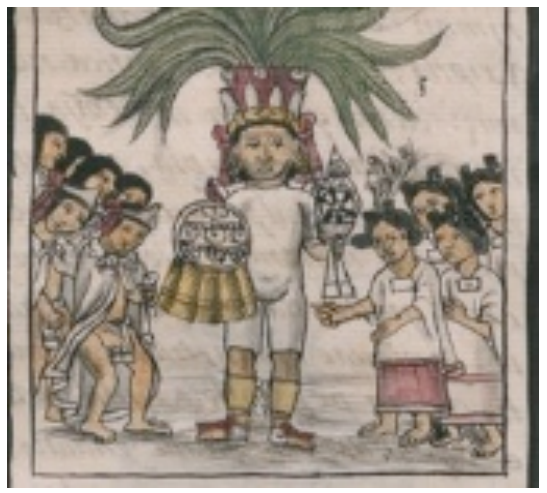

Figure 5-B. Close up of the living representation of Tezcatlipoca from the Florentine Codex accessed via World Digital Library (WDL) on October 2, 2013. http://www.wdl.org/en/item/10613/view/1/37/ 
Returning to Toxcatl, this festival is important because it provides a great example of the Aztec notion of ixiptla. Within this particular ritual, Sahagún explained that the Aztecs chose a man from amongst their captives who maintained the most perfect appearance. After having been chosen, the captive was "reared in all luxuries for the space of a year, [and] trained in the playing [of musical instruments], and in singing, and in speaking" (Sahagún 9; bk. 2). In other words, he was to become Tezcatlipoca both in physical appearance and in mannerisms. As mentioned previously, this practice coincides with the Aztec belief in ixiptla where the captive's human self died and he was ritually transformed into the god Tezcatlipoca. In this sense, the people of Tenochtitlan treated the god-impersonator as if he were the actual god. Sahagún noted "they bowed before him and worshipped him whenever they met him" (9; bk. 2). After a year of being treated as a god, the captive completed his performance atop the Templo Mayor where he was sacrificed in front of the entire city. Keeping in mind the role of ixiplta, the festival of Toxcatl certainly reinforces the idea of history as a performance. By teaching the captive the characteristics and "moves" of Tezcatlipoca, they are essentially bringing both his character and his history to life.

The representation of Toxcatl in the Florentine Codex is also reminiscent of the political landscape that was displayed in the Codex Borgia. To begin, both codices were produced in Central Mexico. Therefore, both represent the seat of power at the time and thus prevalent attitudes towards death. They also provide a pictorial representation of social hierarchy within the Aztec society situating the gods on top and humans on the bottom, but also allowed for the lines between the human and divine worlds to be blurred through ixiptla ritual sacrifice. This is evident in Figure 5-B. This image, taken from the Florentine Codex, depicts the concept of ixiptla during the festival of Toxcatl. In this image the central, and prominent 
figure is the god Tezcatlipoca who is being played by the ixiptla. Like the previously discussed images from the Codex Borgia (particularly Figure 3-A/B which represents the god of death or the underworld, Mictlantecuhtli), the god here is represented as the prominent figure thanks to his size and position. Humans surround the ixiptla with their heads descending towards the center, forcing the eye of the viewer to the center of the image, where the ixiptla is located. The ixiptla is also given priority, as he is nearly twice the height of the surrounding humans. In Aztec iconography size did matter and indicated hierarchical importance.

Apart from a hierarchy with the gods, the Florentine Codex reveals a hierarchal structure within the Aztec society. This bears particular importance when discussing death and the differentiation between one's final destinations in the afterlife. Sahagún explained that the Aztec's believed that once they died their soul would travel to one of three places, but everyone went to the first destination: Mictlan, or the "Place of the Dead". However, depending on one's social standing and how they died determined the length of their journey to get there. For example, the journey to Mictlan generally lasted four years. Yet, if the deceased was sacrificed, it was cut down to four days (Graulich, "Miccailhuitl: The Aztec Festivals of the Deceased" 251). Considering that death through sacrifice shortened the time to reach Mictlan, it is becomes clear that the Aztecs promoted certain members of society over others.

Sacrificial victims were not the only people who were honoured in death. In fact, continuing with the Aztec journey in the afterlife, upon their arrival to Mictlan, it was possible to continue their journey further on to Tlalocan, "Paradise or the Place of Tlaloc". This place was reserved for those who were chosen by Tlaloc, "He Who Makes Things Sprout”. Because he was the Aztec rain god, those who were chosen by him generally died in association with water. This 
included those who had been "struck by thunderbolts, and those who had been submerged in water, and those who had drowned" (Sahagún 47; bk. 3). In addition, they also included those who died of water diseases such as "pustules, and those afflicted by hemorrhoids, and those afflicted by skin sores...festering...gout, etc." (47; bk. 3).

Traditionally, as seen in the Codex Borgia, bodies were bundled and then cremated. In the Florentine Codex, Sahagún noted that men were cremated with their possessions. Sahagún notes: "when men died, [their kin] burned with them all their baskets with insignia the things [they had wrested] from their captives, and all their capes, and all which had been their various clothing" (43; bk. 3). Once they were burnt, they cleansed the body by throwing "water on him, they kept wetting him, they made a slush" (45; bk. 3). After the creation of the 'slush' they "dug a round hole in which to place it...thereupon they put the charcoal in. There they covered the pit" (45; bk. 3)

The funerary rites of the bodies of those chosen by Tlaloc differed to the traditional bundle and cremation as the bodies of the deceased were buried instead. Before being buried; however, "they applied liquid rubber to their faces...and they gave them each a paper lock of hair at the back of the head" (Sahagún 47). The differentiation in the treatment of the body (to imitate the iconography of Tlaloc) demonstrated that those chosen by Tlaloc were situated above those who spent their afterlife in Mictlan.

Although those in the afterlife who went to Tlalocan were situated near the top of the social hierarchy of death, it was not the top realm. Rather, it was reserved for those people who were destined for the third heaven, or the "Place of the Sun". Those who went there included: those "who died in war [...] in battle [...] in the warring place" (Sahagún 49). Women who died in childbirth also went to this glorified military heaven. This heaven is described in the Florentine 
Codex as it was said that after having spent four years in the "Place of the Sun" they [warriors or women who died in childbirth] changed into precious birds...hummingbirds, orioles, yellow birds, yellow birds blackened about their eyes, chalky butterflies" (Sahagún 49). In this instance, we get a sense of how Aztec militaristic discourse was glorified by linking it to the recycling ecology of humans, gods and the natural world.

Other treatments of the body after death also reveal the aspect of performance surrounding social hierarchy. For example, bodies belonging to those of the nobility were decorated in an elaborate fashion. Precious green stones were placed in their mouths and they were adorned with "a noble paper streamer either four fathoms or three fathoms [in length], of paper, which they glued together" (Sahagún 45). Upon this paper creation they "hung various feathers, dark yellow parrot feathers [and] scarlet macaw wing feathers" (Sahagún 45). Thus, nobles were lavishly decorated with precious stones and bird feathers, which were linked to the precious "Place of the Sun" that warriors went to if they died in battle.

Before we proceed, it will be important first to draw attention to the paper streamers just described. These paper flags or streamers were also mentioned in the description of the preparation of the bodies of those chosen by Tlaloc as Sahagún noted "they gave them each a paper lock of hair at the back of the head" (47). Thus, the presence of paper as a funerary adornment in the Florentine Codex is a continuation from the Codex Borgia. This is evident in Figures 4-A and $\mathrm{B}$, which displayed the deceased gods wrapped in the mummy bundle. Behind these figures, you can see the paper streamers represented as banners or flags.

Returning back to the hierarchy in death practice, the elaborate display of material possessions was not the only demonstration of authority for the elite in death. Sahagún also noted that a nobleman 
never died alone. In most cases, the commoner Indians "became their companions [of the dead one] the beloved slaves, perchance a score of the men as well as so many of the women" (Sahagún 45). These people were sacrificed to accompany the nobleman in the afterlife so that they were never without certain amenities.

The commoners, on the other hand, did not experience the same benefits in death. First, instead of a mouth of green stones, they used "only greenish [stones] or obsidian" (45). Next, and perhaps more importantly, the commoners were the ones who were sacrificed to accompany the nobleman. Like the nobleman, their bodies were cremated, but "they did not burn with the ruler" (Sahagún 46). Rather, the ruler was separated from the others and was burnt alone. Thus, by segregating the commoners, the Aztecs displayed the power the nobility had over their society.

The differentiation of nobility in death is also evident in another centrally produced codex: the Codex Mendoza. The Codex Mendoza was produced in late sixteenth-century Mexico. It was prepared with the intention of giving it to King Charles $\mathrm{V}$ under the guidance of the first Viceroy of New Spain, Don Antonio de Mendoza, who is was later named after. Upon completion, the codex was sent to the island of Hispaniola, where it was shipped to Europe. The ship that carried the codex was attacked by French privateers. From there, it came into possession of André Thévet, Royal Cosmographer to King Henry II of France. It was later purchased by Richard Hakluyt; and in 1616 passed to Samuel Purchas and then to John Seldon, who bound it in vellum. At his death, the Codex Mendoza found its way to the Bodleian Library at Oxford, where it currently resides.

The Codex Mendoza consists of 71 pages, which are divided into three sections. The fist section recalls the history of the Aztec people from the founding of Tenochtitlan to the Spanish Conquest. The second lists the towns conquered by the Aztec Empire. It also 
includes an inventory of all the tribute paid by the conquered. Finally, the third section depicts the daily lives of the Aztec people.

Regarding the style of the Codex Mendoza, like the Florentine Codex, it was 'perceptual'. It depicted human figures, architectural, and geographic forms in a naturalistic manner by employing techniques like shading, modeling, and hatching. In addition, the figures within these images were explained or translated using Spanish alphabetic text. Lastly, like the Florentine Codex, it was also organized into a European book format and read in western tradition from front to back.

While it does share stylistic parallels with the Florentine Codex, the Codex Mendoza also demonstrates similarities with the earlier Codex Borgia as well. For example, both codices represent death of the elite in the mummy bundle. This is evident when comparing figures 4-A and B from the Codex Borgia with Figure 6 from the Codex Mendoza. When comparing the two, it is clear that both figures are placed in the typical mummy bundle. Also, both mummybundles are perched upon a noble reed matt or throne and with their eyes closed. Finally, each mummy bundle has a crown upon their heads. Unlike the gods depicted in Figure 4-A and B of the Codex Borgia, Figure 6 from the Codex Mendoza depicts the third Emperor of Tenochtitlan, Chimalpopoca ("Smoking Shield") and his regal crown indicative of his elite status in the Aztec society. 


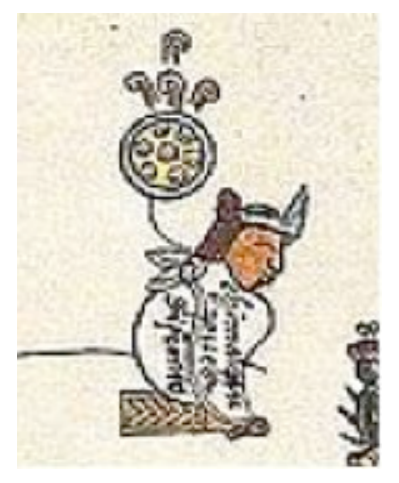

Figure 6. Third Aztec Emperor of Tenochtitlan, Chimalpopoca ("Smoking Sheild") represented in a mummy bundle. Kurt Ross. Codex Mendoza: Aztec Manuscript. 23.

Aztec kings and emperors, however, were not always represented in a mummy bundle. In fact, Figure 7, taken from the Codex Mendoza, clearly represents an exception to this rule. This image represents the death of Moquihuiz, the lord of Tlatelolco (one of the two polities that formed the Aztec empire along with Tenochtitlan) being thrown off the side of the Templo Mayor of Tlatelolco. In her study of the centrally produced Mexican colonial Codex Duran (1581), Emily Umberger explains that this image represented the 1473 civil war between Tenochtitlan and Tlatelolco and was staged to re-enact (in the actual war, this colonial codex, and in the burial practices of this defeated lord) the foundational myth of the warfaring Aztec god Huitzilopochtli. According to Ann De León, Huitzilopochtli ("Hummingbird to the left") defeated and mutilated the body of his combative and rival sister Coyolxauhqui ("Face painted with bells") as she had planned to assassinate him while he was in the womb of their mother Coatlicue ("Her serpent skirt"). Here, in the Codex Mendoza, the Lord of Tlatelolco is depicted in a very awkward, unflattering position that is reminiscent of the freefloating humans shown in the earlier pre-Colombian Codex Borgia (Figure 4). Nonetheless, unlike the humans in Figure 4, the Lord of Tlatelolco is still in full regalia, according him a certain level of 
respect due to his position. Thus, the representation of the defeat of the Lord of Tlatelolco, in an unflattering yet respectful way here was meant to replicate the myth of the demise of Coyolxauhqui, Huitzilopochtli's rival to the Aztec empire. In fact, Umberger notes that the defeated Lord of Tlatelolco was later buried in a funerary vessel beside the Great Coyolxauhqui stone, which was discovered in the 1970s at the Templo Mayor at Tenochtitlan. This was most likely a symbolic and material act to reinforce and memorialize the subjugation of competing claims to the Aztec empire, be they from Coyolxauhqui or Moquihuiz.

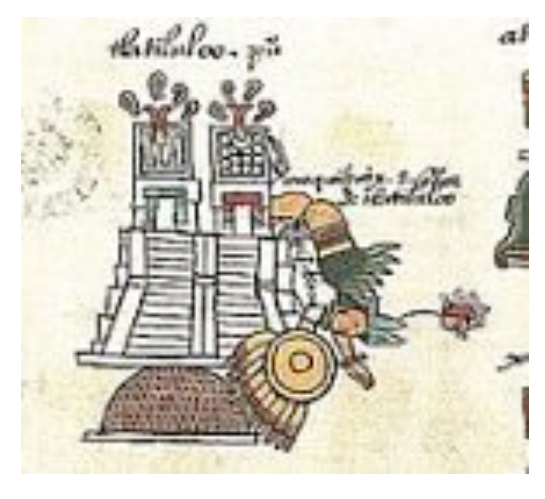

Figure 7. Lord of Tezcoco falling off the side of the temple. Kurt Ross. Codex Mendoza: Aztec Manuscript. 28.

The effects of guided syncretism and incorporation of Christian beliefs onto Aztec traditions on death is most apparent in the $16^{\text {th }}$ century Codex Telleriano-Remensis. Unfortunately, there is little known about the origins of the Codex Telleriano-Remensis apart from the fact that it was painted by an indigenous artist and annotated by at least one writer who lived and died in Mexico. Like the previous codices addressed so far, the Telleriano-Remensis was centrally produced, so it represented the perspective from the seat of power. What we do know is that it surfaced in sixteenth century France in the collection of Archbishop Le Tellier of Reims, who, after his death, 
donated it to the Bibliothèque du Roi. From there it was rediscovered by Humboldt, who re-named the codex after its previous owner. Currently, the codex resides in the Bibliothèque Nacional de France in Paris.

Throughout its life, the Codex Telleriano-Remensis lost a number of leaves. It is thought that the original manuscript consisted of at least 64 leaves or 128 double-sided pages. Today, it consists of 50 folios. These folios are organized into three distinct sections. The first section describes the calendar of the 20-day ceremonies of the solar and seasonal year, the second acts as a divinatory manual, and the third is a chronicle that spans over five centuries of Aztec history. Regarding the overall style of the codex, again, it follows the same European style as the Florentine Codex and the Codex Mendoza. First, it represents its figures and geography threedimensionally through the use of Renaissance shading techniques. Also, it exhibits alphabetic text and displays new colonial actors such as European priests and conquerors and African peoples and new fauna such as horses, which were brought to Mexico City. This is particularly evident in the third section of the codex, where the history of the Aztecs is recalled.

The Codex Telleriano-Remensis also displays continuities from the earlier Codex Borgia. In Figure 8, which is taken from the Codex Telleriano-Remensis, it is evident that the dead Aztec elite was still represented in the typical mummy bundle and reed matt or throne. The Telleriano-Remensis also displays (Figure 9) the presence of a funerary paper flag, which was discussed as previously appearing in the pre-Conquest Borgia. 


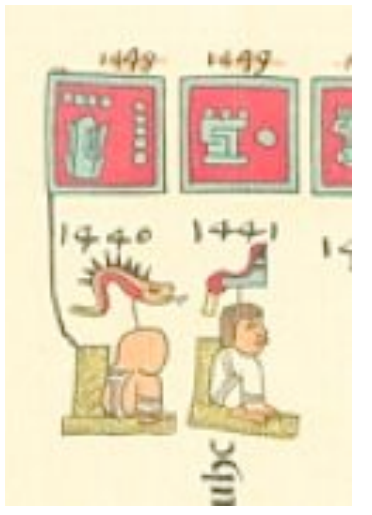

Figure 8. Codex Telleriano-Remensis accessed via the Foundation for the Advancement of Mesoamerican Studies, Inc. (FAMSI) on October 2, 2013.

http://www.famsi.org/research/loubat/Telleriano-Remensis/page_31v.jpg

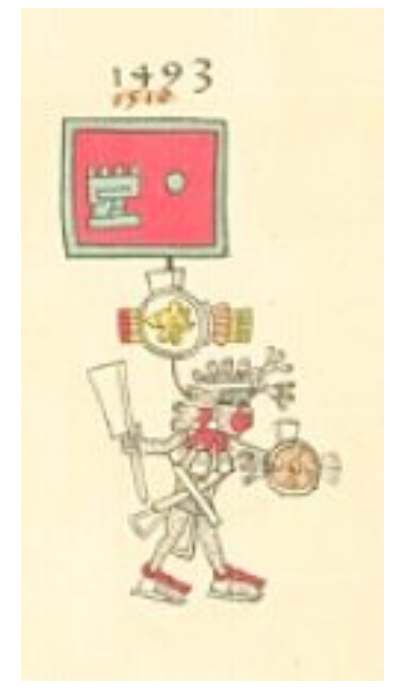

Figure 9. Codex Telleriano-Remensis accessed via the Foundation for the Advancement of Mesoamerican Studies, Inc. (FAMSI) on October 2, 2013. http://www.famsi.org/research/loubat/Telleriano-Remensis/page_40r.jpg

Although the Codex Telleriano-Remensis shares a similar style to the previous two codices (Mendoza and Florentine), it differs in its representation of mass death from either an epidemic or a natural catastrophe. In the Codex Mendoza, mass death was represented as a chain of disembodied heads as shown in Figure 10. In the Codex Telleriano-Remensis, mass death was depicted as a group of anonymous individually wrapped mummy bundles, most likely 
indicating the indigenous commoner as shown on the right of Figure 11. However, unlike the typical elite mummy bundles pictured in the Codex Borgia, these indigenous commoner mummy bundles of Figure 11 are shown lying down in layered rows to suggest mass death (Quinones-Keber 94). Furthermore the alphabetic Spanish text, which accompanied this image, reconfirms this interpretation "año de 1444 y de mil quinientos y cuarenta y cinco una gran mortandad entre los indios" ("between 1444 and 1555 many Indians died" - TB).

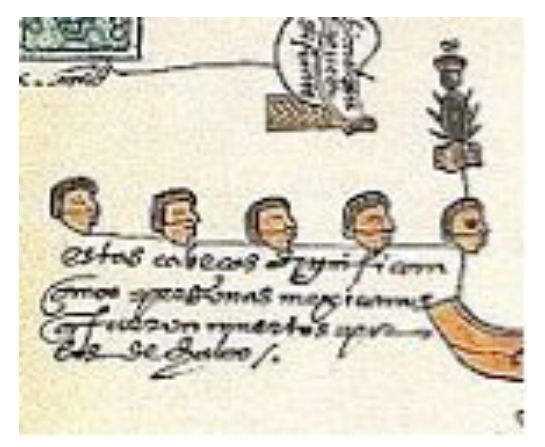

Figure 10. Representation of Death from a Natural Catastrophe or a Massive Epidemic. Kurt Ross. Codex Mendoza: Aztec Manuscript. 23.

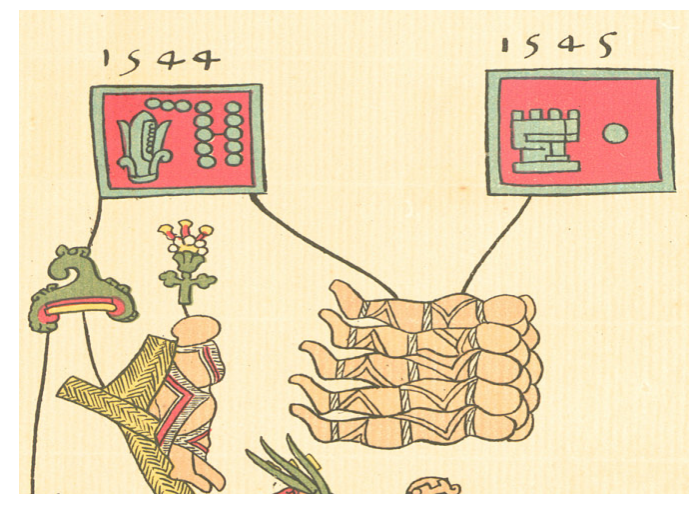

Figure 11. Representation of Death from a Natural Catastrophe or a Massive Epidemic from the Codex Telleriano-Remensis accessed via the Foundation for the Advancement of Mesoamerican Studies, Inc. (FAMSI) on October 2, 2013. 
Despite this stylistic difference of representing the mass death of Indian commoners, or macehualtin, as seen in Figure 11 (a theme not present in pre-Conquest codices like the Borgia which only dealt with the representation of death of gods and lords), the TellerianoRemensis also presents similarities to the previous codices discussed. In particular, it demonstrates that even during colonial times, the surviving Aztec elite still aimed to preserve power and hierarchy. If we compare the elite single mummy bundle represented on the left side of Figure 11 in the Codex Telleriano-Remensis with that from the mummy bundle in Figure 6 of the Codex Mendoza, we can conclude that it was imperative even after the Conquest of Tenochtitlan, that the elite Aztec deceased be still represented as perched upon a throne or reed matt with symbolic funerary attire. This shows how the post-Conquest Aztec elite still aimed to preserve their status and power even after death.

Conclusion: Día de los Muertos as a Reflection and Refraction of Aztec attitudes on death and the afterlife

While the focus of this essay has not been the contemporary Mexican celebration of Día de los Muertos, given its pre-Hispanic origins, it will be interesting to reflect upon how it may represent continuity and change with regards to Aztec representations of and attitudes towards death and the afterlife. Día de los Muertos is a holiday that commemorates the dead through various traditions, one of which involves the creation of ofrendas, or altars, containing offerings to remember and celebrate a deceased loved one or relatives. Ofrendas usually contain many offerings such as pan de muerto (bread for the dead), flowers, colourful paper cut in various designs, alcoholic beverages, hot chocolate, and copal resin incense or sugar skulls. Realistically, it can be anything that the deceased enjoyed while they were living. These offerings are then placed upon 
a shrine or the tomb of the deceased so that when the dead return on the Day of the Dead they might enjoy them and spend time in spirit form with their living relatives.

Some traditional Aztec burial practices and funerary rights (alongside Christian traditions) have continued today. Just as the pre-Hispanic Aztecs elaborately celebrated the dead (especially gods and lords) with lavishly decorated and choreographed rituals, sacrifices of god-impersonators, and feasts; participants in the Day of the Dead today continue to decorate ofrendas with special symbolic paper, food and objects in a similar manner as occurred in earlier times. While such celebrations are no longer the exclusive domain of the indigenous elite, and while human sacrifice is no longer a component of the cyclical debt-payment to maintain the cosmos, the act of creating ofrenda shrines could be seen in part as a continuation of pre-Hispanic Aztec beliefs and attitudes towards death. By placing these gifts on the tombs of the dead, contemporary descendants of the Aztecs are acknowledging that the deceased are still a part of living society. Therefore, the Mexican people could be seen as reenacting the past by bringing their ancestors back, feeding and preparing drinks for them, singing to them, and thus blurring the lines between the living and the dead.

To conclude, through the iconographic analysis of the representation of death and the afterlife in some pre- and postConquest codices from the central valley of Mexico (the seat of Aztec power), there is clear evidence for both continuity and change in the representation and attitudes towards death and the afterlife. More specifically, all the discussed codices touch on the notion of performativity and preserving the hierarchal structure of Aztec society even in death. 


\section{Works Cited}

Arnold, Philip P. Eating Landscape: Aztec and European Occupation of Tlalocan. Niwot: University Press of Colorado, 1999. Web.

Bădescu, Gabriel and Paul E. Sum. "Historical Legacies, Social Capital and Civil Society: Comparing Romania on a Regional Level." Europe-Asia Studies 57.1 (2005): 1-169. Print.

Baird, Ellan T. "Adaptation and Accommodation: The Transformation of the Pictorial Text in Sahagun's Manuscripts." Native Artists and Patrons in Colonial Latin America. Ed. Emily Umberger and Tom Cummins. Tempe Arizona: Arizona State University, 1995. 36-51. Print.

Baquedano, Elizabeth. "Concepts of Death and the Afterlife in Central Mexico." Living with the Dead: Mortuary Ritual in Mesoamerica. Ed. James L. Fitzsimmons and Izumi Shimada. Tuscon: University of Arizona Press, 2011. 203-230. Print.

Berezin, Mabel. "Minority Rights and Majority Rule: Ethnic Tolerance in Romania and Bulgaria." Social Forces 73.3 (1995): 789-1196. Print.

Blomster, Jeffrey P. "Bodies, Bones, and Burials." Living with the Dead: Mortuary Ritual in Mesoamerica. Ed. James L. Fitzsimmons and Izumi Shimada. Tuscon: University of Arizona Press, 2011. 102-160. Print.

Boone, Elizabeth H. Stories in Red and Black: Pictorial Histories of the Aztecs and Mixtecs. Austin: University of Texas Press, 2000. Print.

Brandes, Stanley. "Iconography in Mexico's Day of the Dead: Origins and Meaning." Ethnohistory 45. 2 (Spring, 1998): 181-218. Print.

Brandes, Stanley. "Sugar, Colonialism, and Death: On the Origins of Mexico's Day of the Dead." Comparative Studies in Society and History 39. 2 (1997): 270-299. Print.

Burkhart, Louise M. The Slippery Earth: Nahua-christian Moral Dialogue in Sixteenth-Century Mexico. Tucson: University of Arizona Press, 1989. Print.

Carrasco, David. City of Sacrifice: The Aztec Empire and the Role of Violence in Civilization. Boston: Beacon Press, 1999. Print. 
De León, Ann. "Coatlicue or How to Write the Dismembered Body." $M L N$ (Hispanic Issue), Volume 125, Number 2, (March 2010): 259-286. Print.

Díaz, Gisele, Alan Rodgers, and Bruce E. Byland. The Codex Borgia: A Full-Color Restoration of the Ancient Mexican Manuscript. New York: Dover Publications, 1993. Print.

Graulich, Michel. "Miccailhuitl: The Aztec Festivals of the Deceased." Numen 36.1 (Jun., 1989): 43-71. Print.

-------. Myths of Ancient Mexico. Norman: University of Oklahoma Press, 1997. Print.

Habenstein, Robert W, and William M. Lamers. Funeral Customs the World Over. Milwaukee: Bulfin Printers, 1963. Print.

Klein, Cecelia F. "Post Classic Mexican Death Imagery as a sign of Cyclic Completion." Death and the Afterlife in Pre-Columbian America: A Conference at Dumbarton Oaks, October 27th, 197. Ed, Emily P. Benson. Washington: Dumbarton Oaks Research Library and Collections, Trustees for Harvard University, 1975. 69-86. Print.

León, Portilla M. Aztec Thought and Culture: A Study of the Ancient Nahuatl Mind. Norman: University of Oklahoma Press, 1963. Print.

Lockhart, James. The Nahuas After the Conquest: A Social and Cultural History of the Indians of Central Mexico, Sixteenth Through Eighteenth Centuries. Stanford, Calif: Stanford University Press, 1992. Print.

Lomnitz-Adler, Claudio. Death and the Idea of Mexico. Brooklyn, N.Y: Zone Books, 2005. Print.

López, Austin A. The Human Body and Ideology: Concepts of the Ancient Nahuas. Salt Lake City: University of Utah Press, 1988. Web.

Mills, Kenneth, and William B. Taylor. Colonial Spanish America: A Documentary History. Wilmington, Del: Scholarly Resources, 1998. Print.

Monaghan, John. "Performance and the Structure of the Mixtec Codices." Ancient Mesoamerica 1.01 (Spring 1990): 133-140. Web. 
Nicholson, H B. Topiltzin Quetzalcoatl: The Once and Future Lord of the Toltecs. Boulder: University Press of Colorado, 2001. Print.

Nutini, Hugo G. Todos Santos in Rural Tlaxcala: A Syncretic, Expressive, and Symbolic Analysis of the Cult of the Dead. Princeton, N.J: Princeton University Press, 1988. Print.

Olivier, Guilhem. Mockeries and Metamorphoses of an Aztec God: Tezcatlipoca, "Lord of the Smoking Mirror". Boulder: University Press of Colorado, 2003. Print.

Quiñones, Keber E. Codex Telleriano-Remensis: Ritual, Divination, and History in a Pictorial Aztec Manuscript. Austin: University of Texas Press, 1995. Print.

Ross, Kurt. Codex Mendoza: Aztec Manuscript. Barcelona, Spain: Miller Graphics, 1978. Print.

Sahagún, Bernardino, Arthur J. O. Anderson, and Charles E. Dibble. General History of the Things of New Spain: Florentine Codex. Santa Fe, N.M: School of American Research, 1950. Print.

Schroeder, Susan. The Conquest All Over Again: Nahuas and Zapotecs Thinking, Writing, and Painting Spanish Colonialism. Eastbourne: Sussex Academic Press, 2010. Print.

Taylor, Diana. "Performance and/as History." The Drama Review 50.1 (Spring 2006): 67-86. Web.

Umberger, Emily. "The Metaphorical Underpinnings of Aztec History. The case of the 1473 civil war." Ancient Mesoamerica Volume 18.1 (Spring 2007) : 11-29. Web.

Will, de C. M. Death and Dying in New Mexico. Albuquerque: University of New Mexico Press, 2007. Print. 
Tanya Ball is an M.A. student in the department of Modern Languages and Cultural studies, specialising in Spanish and Latin American Studies. Her research interests include Aztec religion and ist appropriation after the conquest; as well as natural disasters and catastrophes in seventeenth century Guatemala.

tcball@ualberta.ca 